\title{
Aerated steel slag filter system performance study for pollutants removal from domestic wastewater
}

\author{
Hamdan, R. ${ }^{1^{*}}$ and Izzati Izwanni Ibrahim ${ }^{1}$ \\ ${ }^{1}$ Department of Civil Engineering, Faculty of Engineering Technology, UTHM
}

\begin{abstract}
Nitrogen removal from wastewater often requires a highly cost of chemical treatment to prevent over loading of nutrient in effluent discharge to the surface water body. However, to remove nitrogen it requires a complex process. Therefore, the aim of this study is to develop an aerated rock filter (ARF) system design under Malaysia condition. A pilot-scale VFARF with $2.0 \mathrm{~m}$ height and $0.3 \mathrm{~m}$ diameter and a HFARF with $1.0 \mathrm{~m}$ long and $0.3 \mathrm{~m}$ wide and $0.5 \mathrm{~m}$ height has been developed at Taman Bukit Perdana Wastewater Treatment Plant (WWTP) Batu Pahat, Johor to monitor the performance of the ARFs for nitrogen removal from domestic wastewater. The optimum value of HLR and aeration rate was $2.72 \mathrm{~m}^{3} / \mathrm{m}^{3}$.day and $10 \mathrm{~L} / \mathrm{min}$, respectively. For monitoring the effectiveness of the VFARF and HFARF, influent and effluent twice a week grab samples have been collected and analysed for TKN, Ammonia Nitrogen, $\mathrm{BOD}_{5}, \mathrm{COD}$, TSS, Alkalinity, $E$-coli, $\mathrm{pH}$, Dissolved Oxygen and Temperature. From the study, it was found that the VFARF system has outperformed as the removal efficiency of TKN, AN, TSS, and E-coli was $89 \% \pm 7 \%, 97 \% \pm 2 \%, 86 \% \pm 17 \%$, and $97 \% \pm 2 \%$. The removal efficiency was slightly lower in the HFARF as their removal was $78 \% \pm 11 \%, 71 \% \pm 12 \%, 88 \% \pm 15 \%$, and $91 \% \pm 16 \%$ for TKN, AN, TSS, and $E$-coli. However, their performance insignificant in removing organic matter, $\mathrm{BOD}_{5}, \mathrm{COD}$ as the removal efficiencies in the VFARF and HFARF were $84 \% \pm 13 \%, 65 \% \pm 23 \%$ and $85 \% \pm 12 \%, 75 \% \pm 21 \%$, respectively. Alkalinity, $\mathrm{pH}$ and DO profiles for VFARF and HFARF systems effluent values were average at $107.08 \pm 28.35 \mathrm{mg} / \mathrm{L}, 7.14 \pm 0.27,5.20 \pm 0.84 \mathrm{mg} / \mathrm{L}$, $147.24 \pm 16.20 \mathrm{mg} / \mathrm{L}, 6.99 \pm 0.15$ and $3.75 \pm 0.37 \mathrm{mg} / \mathrm{L}$, respectively. Temperature value for this VFARF and HFARF system was $31.1 \pm 1.1^{\circ} \mathrm{C}$. From monitoring study between VFARF and HFARF, it found that VFARF system was outperformed than the HFARF in removing nitrogen from domestic wastewater.
\end{abstract}

Keywords: Domestic Wastewater, Horizontal flow aerated rock filter, Hydraulic loading rate, Vertical flow aerated rock filter.

\section{Introduction}

Nowadays, eutrophication problems in developing countries are related to high nutrient in domestic wastewater discharge. Human activities have accelerated the rate and extent of eutrophication through both pointsource discharges and non-point loadings of limiting nutrients, such as nitrogen that contain high ammonia into aquatic ecosystems (i.e., cultural eutrophication), with dramatic consequences for drinking water sources, fisheries, and recreational water bodies as indicated in [1]. Discharge from incomplete treatment of nutrient from wastewater could be the main culprit of the above mentioned problem. However, to remove nitrogen from domestic wastewater with high nutrient using conventional system are expensive due to utilization of chemicals, high operational and maintenance cost, lack of treatment capacity, efficiencies, stability and space requirements [2]. Therefore, the demand of appropriate low-cost technology and an economic effective system are crucial as an improvement to the existing treatment systems for treating high nutrient wastewater and towards the new effluent discharge compliance.

\footnotetext{
* Corresponding author: rafidahh@uthm.edu.my
}

Rock filter system has been invented more than 30 years ago in the US with the main purpose of removing organic matters and algae from wastewater. However, due to the system was rapidly turned to anoxic condition with limited removal of ammonium nitrogen in the system effluent [3]. Therefore, aerated system has been explored to enhance the removal of ammonium nitrogen from domestic wastewater in the UK [4]. Aerated Rock Filter (ARF) emerged as one of the attractive treatment system for nitrogen removal as the system is simple to operate, low operation and maintenance costs, low energy requirements, and overall 'low technology' [5]. However, information on the performance of the ARF under various operating and environmental conditions is still lacking in terms of the impact different organic and HLR [2]. Hence, this study was focused on the ARF system performance monitoring of optimum HLR and aeration rate with steel slag as filter media in pollutants removal from domestic wastewater. 


\section{Experimental}

\subsection{Set-up for VFARF and HFARF Performance Study on Nitrogen Removal}

Primarily treated domestic wastewater was pumped using peristaltic pumps (Watson Marlow into the vertical flow ARF and horizontal flow ARF base using $15 \mathrm{~mm}$ reinforced plastic pipework connected to a polyninyl chloride inlet strainer heads located at the base of both ARF systems. In addition, both ARF was installed with air flow meters and aerated by using JUN Air Compressor as described in Figure 1. The system was controlled by the required HLR and air flow rate that is $2.72 \mathrm{~m}^{3} / \mathrm{m}^{3}$.d and $10 \mathrm{~L} / \mathrm{min}$, respectively. Both filters were filled with the steel slag as filter media. The filters were run for 2.5 months. The influent and effluent of the VFARF and HFARF were collected twice a week for laboratory analysis on selected parameters including BOD, COD, TSS, TKN, AN, Alkalinity, Nitrate, Nitrite, $\mathrm{pH}, \mathrm{DO}$, Temperature and E-coli according to Standard Methods for Water and Water Examinations [6] at Wastewater Laboratory, UTHM.

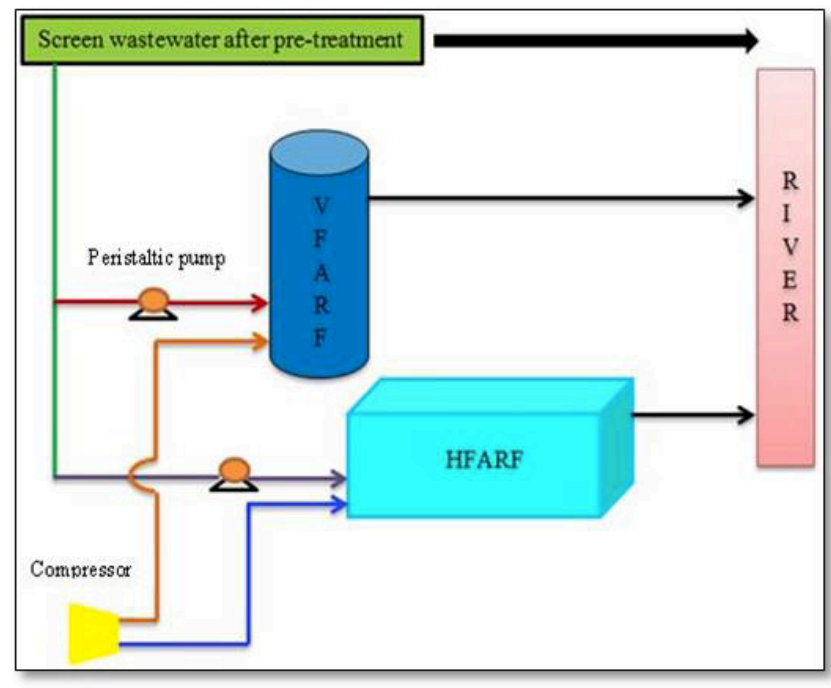

Figure 1. Layout of the experiment

\section{Result and Discussion}

\subsection{The Performance of VFARF and HFARF System}

The wastewater quality monitoring of VFARF and HFARF performance was took place in two months, from $13^{\text {th }}$ November 2014 until $14^{\text {th }}$ January 2015 at WWTP Taman Bukit Perdana, Batu Pahat, Johor. During the monitoring period, the wastewater influent and effluent were collected twice a week for laboratory analyses. This monitoring experiment was necessary to compare the performance between VFARF and HFARF in terms of removal of nitrogen. The removal efficiencies, influent and effluent concentration for monitoring parameters for both VFARF and HFARF are provided in Table 1. Based on the removal efficiency shown, the VFARF system has higher rate in removals compared to the HFARF, whish is more $80 \%$ in terms of $\mathrm{BOD}_{5}, \mathrm{TKN}, \mathrm{AN}, \mathrm{TSS}$, and $E$-coli. The discussion regarding the tabulated data is presented in the further subsections.

Table 1. Summary of monitoring data for the VFARF and HFARF system ${ }^{\text {a }}$

\begin{tabular}{|c|c|c|c|c|c|}
\hline \multirow[b]{2}{*}{ Parameter } & \multicolumn{3}{|c|}{ Sampling Point } & \multicolumn{2}{|c|}{ Removal Efficiency (\%) } \\
\hline & $\begin{array}{c}\text { Influent } \\
\text { conc.'s } \\
\text { (Mean } \pm \text { s.d.) }\end{array}$ & $\begin{array}{l}\text { VFARF } \\
\text { effluent } \\
\text { conc.'s (Mean } \\
\pm \text { s.d.) }\end{array}$ & $\begin{array}{c}\text { HFARF } \\
\text { effluent } \\
\text { conc.'s } \\
\text { (Mean } \pm \text { s.d.) }\end{array}$ & $\begin{array}{c}\text { VFARF } \\
\text { (Mean } \pm \\
\text { s.d.) }\end{array}$ & $\begin{array}{l}\text { HFARF } \\
\text { (Mean } \pm \\
\text { s.d.) }\end{array}$ \\
\hline $\mathrm{BOD}_{5}$ & $\begin{array}{c}266.30 \pm \\
269.71 \\
\end{array}$ & $24.69 \pm 21.62$ & $21.49 \pm 16.39$ & $86 \pm 10$ & $88 \pm 8$ \\
\hline COD & $\begin{array}{c}426.06 \pm \\
343.52 \\
\end{array}$ & $96.64 \pm 49.05$ & $70.78 \pm 52.84$ & $65 \pm 23$ & $75 \pm 21$ \\
\hline TKN & $50.77 \pm 22.47$ & $5.43 \pm 2.39$ & $10.96 \pm 5.57$ & $89 \pm 7^{\mathrm{NE}}$ & $78 \pm 11^{\mathrm{NE}}$ \\
\hline AN & $31.39 \pm 8.96$ & $0.84 \pm 0.62$ & $9.06 \pm 4.27$ & $97 \pm 2^{\mathrm{NE}}$ & $71 \pm 12^{\mathrm{NE}}$ \\
\hline Nitrate-N & $0.00 \pm 0.00$ & $18.65 \pm 6.10$ & $6.42 \pm 2.35$ & n.a & n.a \\
\hline Nitrite-N & $0.00 \pm 0.00$ & $0.00 \pm 0.00$ & $0.00 \pm 0.00$ & n.a & n.a \\
\hline TSS & $\begin{array}{c}601.84 \pm \\
591.16 \\
\end{array}$ & $30.53 \pm 22.91$ & $24.47 \pm 17.86$ & $86 \pm 17$ & $88 \pm 15$ \\
\hline Alkalinity & $\begin{array}{c}314.61 \pm \\
206.98\end{array}$ & $107.08 \pm 28.35$ & $147.24 \pm 16.20$ & n.a & n.a \\
\hline E-Coli & $\begin{array}{l}50949.00 \pm \\
29904.60 \\
\end{array}$ & $\begin{array}{c}405.15 \pm \\
1564.11 \\
\end{array}$ & $\begin{array}{c}2901.50 \pm \\
3715.92 \\
\end{array}$ & $97 \pm 2$ & $91 \pm 16$ \\
\hline DO & $0.19 \pm 0.23$ & $5.20 \pm 0.84$ & $3.75 \pm 0.37$ & n.a & n.a \\
\hline $\mathrm{pH}$ & $6.28 \pm 0.09$ & $7.14 \pm 0.27$ & $6.99 \pm 0.15$ & n.a & n.a \\
\hline Temp, ${ }^{\circ} \mathrm{C}$ & $31.2 \pm 0.7$ & $31.1 \pm 1.1$ & $31.1 \pm 1.1$ & n.a & n.a \\
\hline \multicolumn{6}{|c|}{$\begin{array}{l}\text { Note: All units are } \mathrm{mg} / \mathrm{L} \text { except } \mathrm{pH} \text { and } E \text {-coli }(\mathrm{cfu} / \mathrm{ml}), \text { s.d.= Standard Deviation } \\
(\mathrm{n}=19) ; \mathrm{n} . \mathrm{a} .=\text { not available; }{ }^{\mathrm{NE}}=\text { nitrification efficiency }\end{array}$} \\
\hline
\end{tabular}

\subsection{Biochemical Oxygen Demand $\left(\mathrm{BOD}_{5}\right)$ Removal}

The value of influent concentration in the WWTP is average at $266.30 \pm 269.71 \mathrm{mg} / \mathrm{L} \mathrm{BOD}_{5}$. After two month of monitoring period, the $\mathrm{BOD}_{5}$ effluent was slightly dropped with an average concentration of $24.69 \pm 21.62$ $\mathrm{mg} / \mathrm{L}$ and $21.49 \pm 16.39 \mathrm{mg} / \mathrm{L}$ for the VFARF and HFARF systems, respectively as presented in Figure 2. Meanwhile, the average removal efficiency for VFARF was $86 \% \pm 10$, whilst the average removal of HFARF was $88 \% \pm 8$ as shown in Figure3. Both VFARF and HFARF systems were efficiently removed $\mathrm{BOD}_{5}$ from domestic wastewater and not statistically significant different in terms of removal efficiency and effluent quality as the $p$-value was 0.751 and 0.817 respectively. Both systems were performed well in terms of $\mathrm{BOD}_{5}$ removal. In addition, both systems are able to produce effluent quality within the permissible limit of Standard B which is $50 \mathrm{mg} / \mathrm{L}$ under Environmental Quality (Sewage) Regulations 2009.

The reduction of $\mathrm{BOD}_{5}$ concentration took place as soon as the wastewater in terms of biodegradable organic matters enter the VFARF and HFARF system due to highly aerated filter system with high concentration of dissolved oxygen as well as the porous media within the filters. Furthermore, aerobic degradation of dissolved 
organic matter is developed by the aerobic heterotrophic bacteria. Vymazal in [7] has stated that ammonifying bacteria also degrade organic compounds containing nitrogen under aerobic conditions. The microorganisms use oxygen as a source of energy for growth during the decomposition process of organic carbon to carbon dioxide.

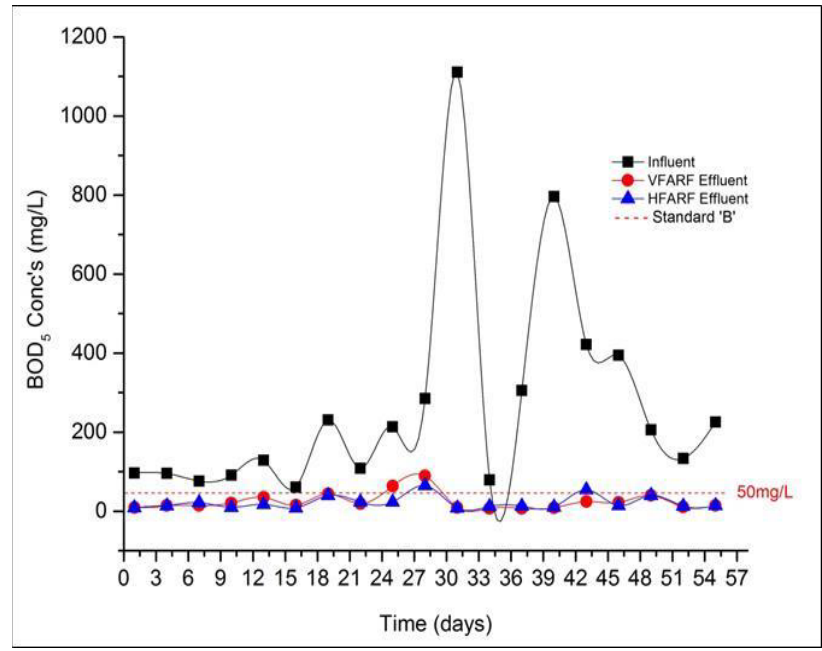

Figure 2. $\mathrm{BOD}_{5}$ concentrations in the WWTP influent and effluent of VFARF and HFARF

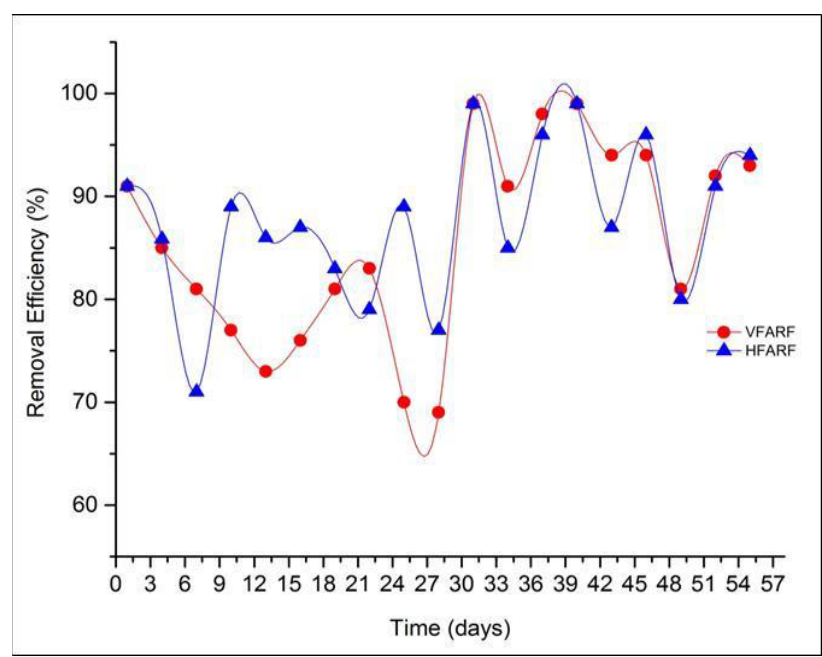

Figure 3. Removal efficiency of $\mathrm{BOD}_{5}$

\subsection{Chemical Oxygen Demand (COD) Removal}

The COD concentration from wastewater influent is at an average $426.06 \pm 343.52 \mathrm{mg} / \mathrm{L}$ then $\mathrm{COD}$ value was reduced to an average $96.64 \pm 49.05 \mathrm{mg} / \mathrm{L}$ for VFARF and $70.78 \pm 52.84 \mathrm{mg} / \mathrm{L}$ for HFARF as provided in Figure 4. In terms of filter performance, the HFARF showed a higher performance than the VFARF in COD removal.

The removal efficiencies were found to be at an average of $65 \% \pm 23$ in the VFARF and $75 \% \pm 21$ in the HFARF as illustrated in Figure 5. Based on the t-test analysis, both VFARF and HFARF systems were efficiently removed COD from domestic wastewater without showing any statistical significant different in terms of removal efficiency and effluent quality as the $p$-value was 0.167 and 0.127 respectively. Some of the COD value might be associated with the suspended solid that settle in the filter. Besides that, COD removal efficiency increased due to the oxygen content in the filter is higher. As for COD, both systems are able to produce effluent quality within the permissible limit of Standard B which is 200 $\mathrm{mg} / \mathrm{L}$.

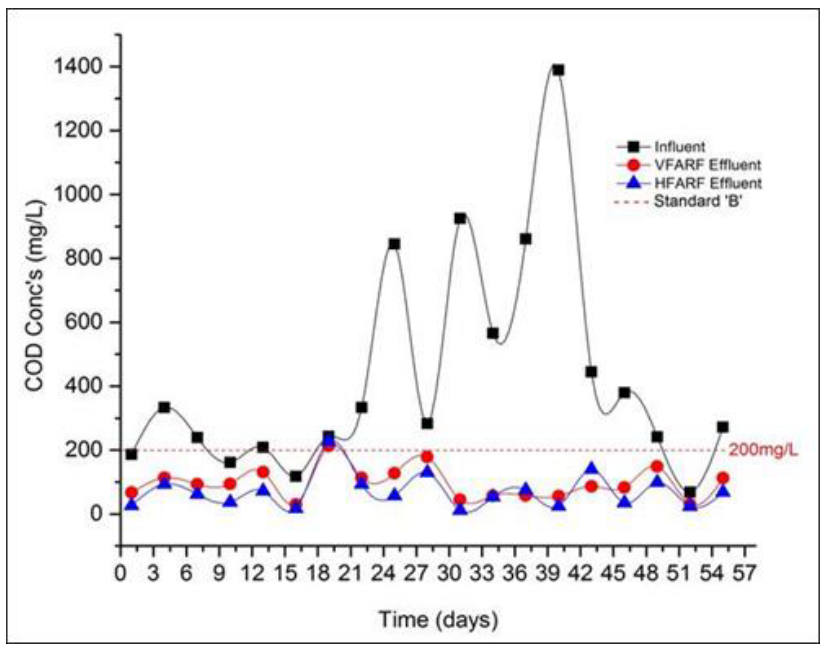

Figure 4. COD concentrations in the WWTP influent and effluent of VFARF and HFARF

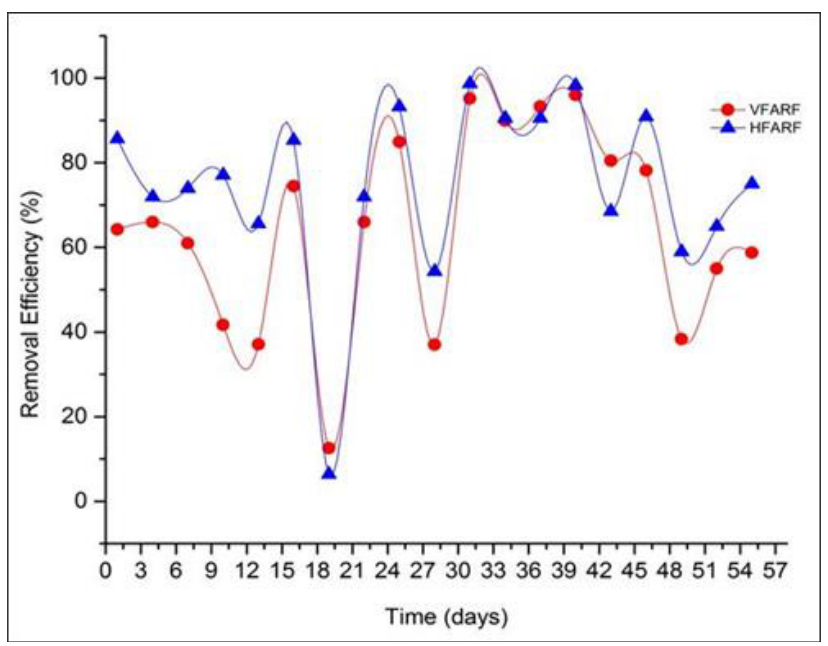

Figure 5. Removal efficiency of COD

\subsection{Total Suspended Solids (TSS) Removal}

The TSS influent concentration entering the VFARF and HFARF systems were produced an average of $601.84 \pm$ $591.16 \mathrm{mg} / \mathrm{L}$ during the monitoring period and after treatment. The VFARF was able to produce an average of $30.53 \pm 22.91 \mathrm{mg} / \mathrm{L}$ in the filter effluent, equal to a removal efficiency of $86 \% \pm 17$. On the other hand, the HFARF achieved $88 \% \pm 15$ of removal efficiency with an average effluent concentration of $24.47 \pm 17.86 \mathrm{mg} / \mathrm{L}$ as provided in Figure 6 and 7. Based on the t-test analysis, the effluent and removal efficiency of TSS results were not statistically significant different as the $p$-value was 0.297 and 0.686 respectively for both VFARF and HFARF systems. From the results, it shows that both 
systems performed well in removing suspended solid. It is proved by the [8] that horizontal subsurface flow provide a higher filtration capability for solid matter removal. In terms of TSS, both systems are able to produce effluent quality within the permissible limit of Standard B which is $100 \mathrm{mg} / \mathrm{L}$.

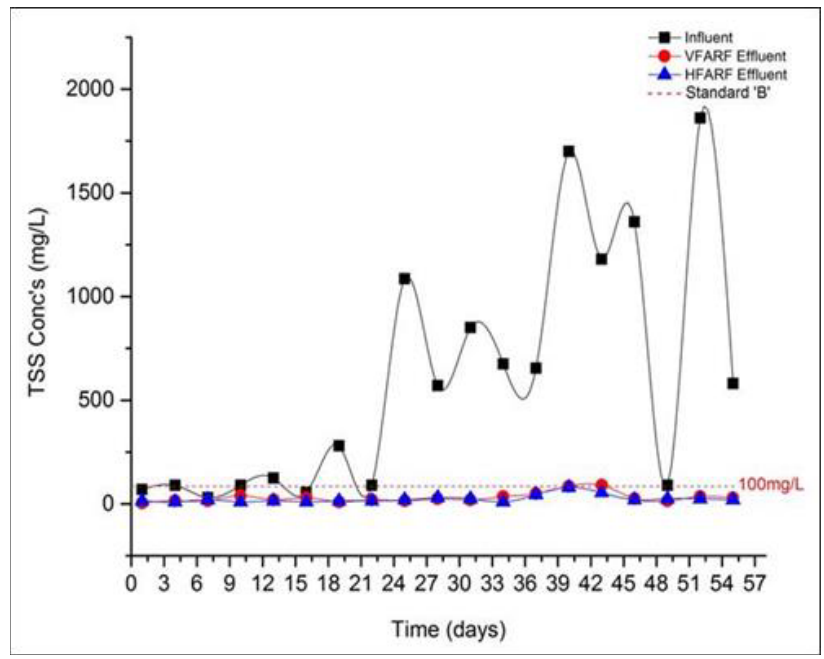

Figure 6. TSS concentrations in the WWTP influent and effluent of VFARF and HFARF

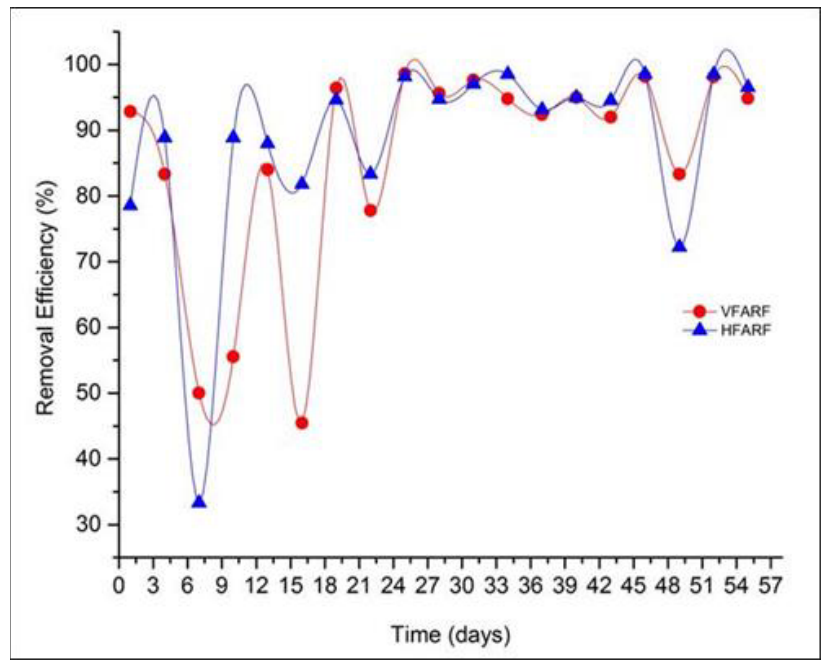

Figure 7. Removal efficiency of TSS

\subsection{Total Kjeldahl Nitrogen (TKN) Removal}

Total Kjeldahl Nitrogen (TKN) represents the sum of organic nitrogen, ammonia nitrogen $\left(\mathrm{NH}_{3}\right)$ and ammonium nitrogen $\left(\mathrm{NH}_{4}{ }^{+}\right)$. However, most of the ammonia in wastewater is found in the form of ammonium ion. TKN concentration in the influent was at an average $50.77 \pm 22.47 \mathrm{mg} / \mathrm{L}$ then was removed after treatment in VFARF and HFARF as their removal efficiencies achieved the averages of $89 \% \pm 7$ and $78 \% \pm$ 11, respectively as shown in Figure 8. Thus, the average final effluent for VFARF was $5.43 \pm 2.39 \mathrm{mg} / \mathrm{L}$ and $10.96 \pm 5.57 \mathrm{mg} / \mathrm{L}$ for HFARF as provided in Figure 9. In terms of TKN removal and effluent quality, VFARF performed better than HFARF and it is also statistically significant different as the $p$-value was 0.000 and 0.002 respectively. From the result obtained, VFARF was successfully reduced the nitrogen from domestic wastewater.

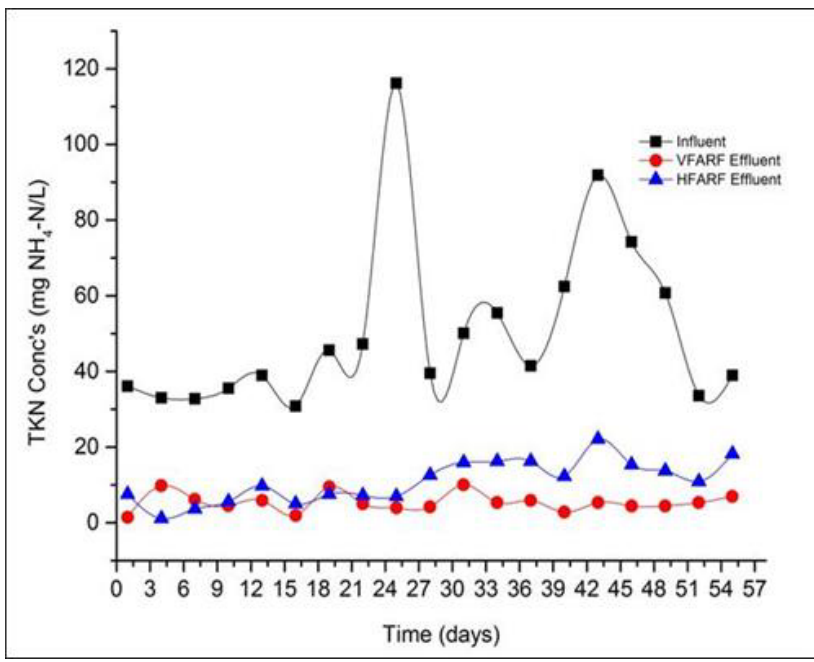

Figure 8. TKN concentrations in the WWTP influent and effluent of VFARF and HFARF

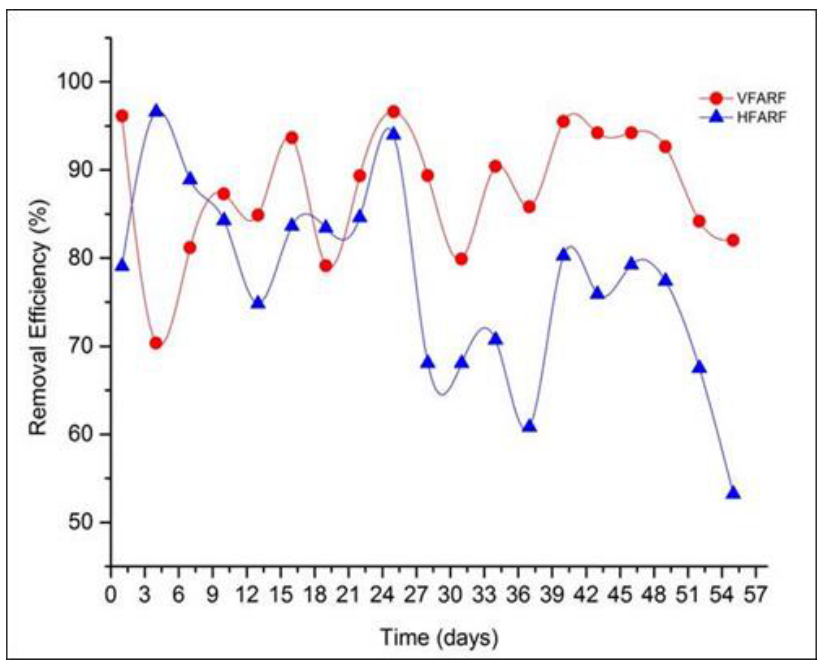

Figure 9. Removal efficiency of TKN

\subsection{Ammonium Nitrogen (AN) Removal}

Ammonium nitrogen (AN) from wastewater had an average of $31.39 \pm 8.96 \mathrm{mg} / \mathrm{L}$ of influent concentration. AN was effectively removed in the VFARF compared to the HFARF. The removal efficiency in the VFARF system averaged $97 \% \pm 2$, which produced an average of $0.84 \pm 0.62 \mathrm{mg} / \mathrm{L}$ in the final effluent. However, the removal efficiency was found to be slightly lower in the HFARF system as achieved an average of $71 \% \pm 12$ AN removal with the final effluent concentration average of $9.06 \pm 4.27 \mathrm{mg} / \mathrm{L}$ as provided in Figure 10 and Figure 11 . From the results it shows that the removal of ammonium nitrogen was excellent in VFARF system compared to HFARF system and it is statistically significant different as the $p$-value was 0.000 for both VFARF and HFARF systems. Both systems were consistently produced good effluent quality and comply with the effluent permissible limit for 'standard B' which is $20 \mathrm{mg} / \mathrm{L}$. From this observation, it shows that nitrification process was took 
place in this treatment system as AN has been well removed under aerobic condition filter system.

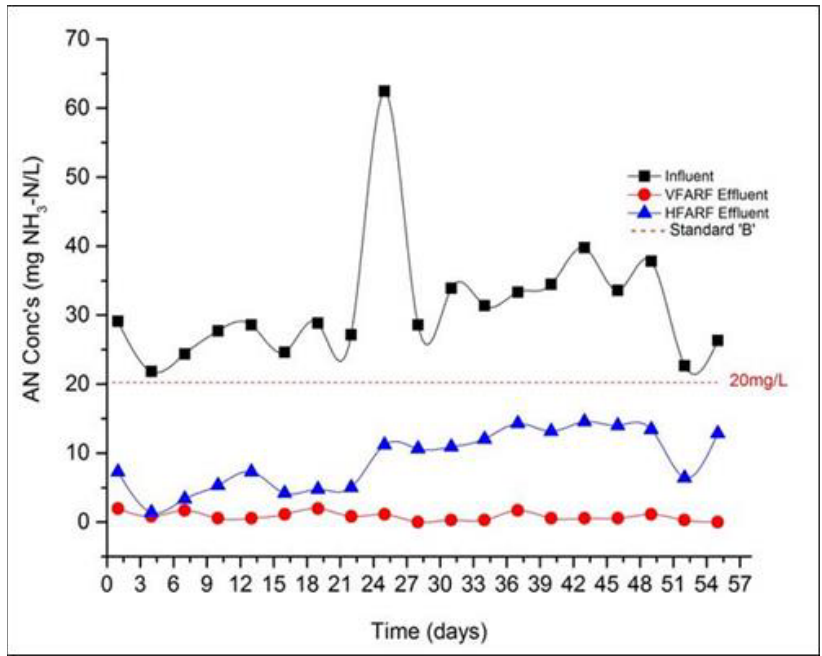

Figure 10. AN concentrations in the WWTP influent and effluent of VFARF and HFARF

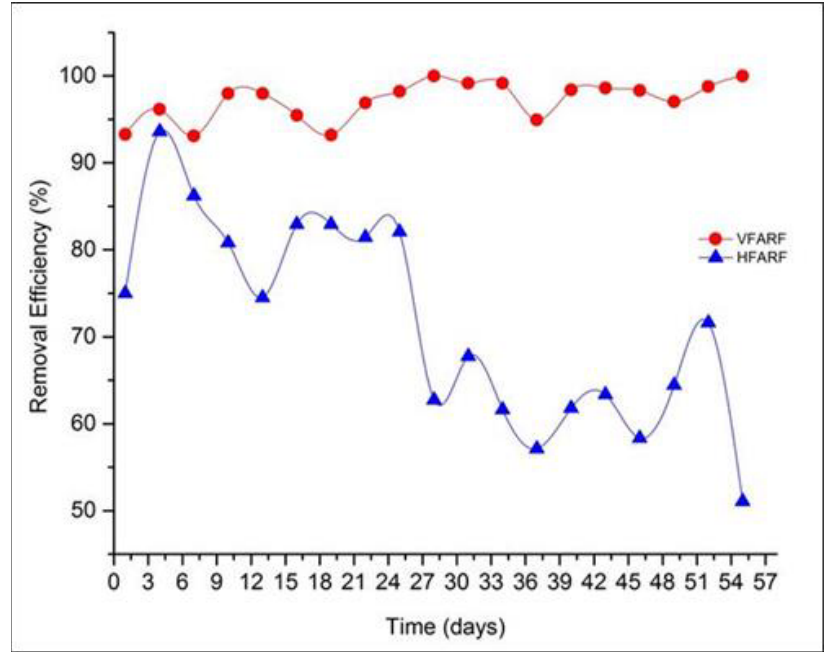

Figure 11. Removal efficiency of AN

Furthermore, dissolved oxygen was found to be higher in the VFARF system with an average $5.20 \pm 0.84 \mathrm{mg} / \mathrm{L}$, whilst an average of $3.75 \pm 0.37 \mathrm{mg} / \mathrm{L}$ was determined in the HFARF system as illustrated in Figure 12. Pertaining to the increasing level of DO in the system, the VFARF system provides more favorable conditions for nitrification to occur as well as further removal of biodegradable organic matters. Therefore, in a highly oxygenated system such as in the $1.5 \mathrm{~m}$ depth of VFARF, more ammonium ions $\left(\mathrm{NH}_{4}^{+}\right)$were oxidized to nitratenitrogen $\left(\mathrm{NO}_{3}-\mathrm{N}\right)$ as compared to the $0.5 \mathrm{~m}$ depth of HFARF due to DO level within the system.

In this experiment, high concentration of nitrate-nitrogen $\left(\mathrm{NO}_{3}-\mathrm{N}\right)$ found in the VFARF effluent shows that nitrification process has taking place as AN has been converted to nitrate with the present of nitrfiers; Nitrosomonas and Nitrobacter. An average concentration of $\mathrm{NO}_{3}-\mathrm{N}$ in the VFARF effluent was $18.65 \pm 6.10 \mathrm{mg} / \mathrm{L}$ whilst in the HFARF the average was $6.42 \pm 2.35 \mathrm{mg} / \mathrm{L}$ as shown in Figure 13. Effluent quality from both systems within permissible limit of 'Standadr B' which is
$50 \mathrm{mg} / \mathrm{L}$. From this observation, conversion of $\mathrm{NO}_{3}-\mathrm{N}$ was slightly higher in the VFARF compared to the HFARF. This condition shows that nitrification rate was slightly higher in the system with higher $\mathrm{NO}_{3}-\mathrm{N}$ concentration in final effluent. Therefore, this observation then supported by nitrification data that was relatively higher in the VFARF system compared to the HFARF system as illustrated in Figure 14. The average of nitrification efficiency in the VFARF and HFARF were $97 \% \pm 2$ and $71 \% \pm 12$ respectively. The rate of nitrification was found to be higher in VFARF system and it is statistically significant different as the $p$-value was 0.000 for VFARF and HFARF Therefore, the VFARF is more effective than the HFARF. Furthermore, according to [9], vertical flow rock filters mostly perform better than horizontal flow systems as ones located in Veneta, Oregon and West Monroe, Louisiana. Theoretically, the rates of nitrification are higher when the DO levels in the system are higher.

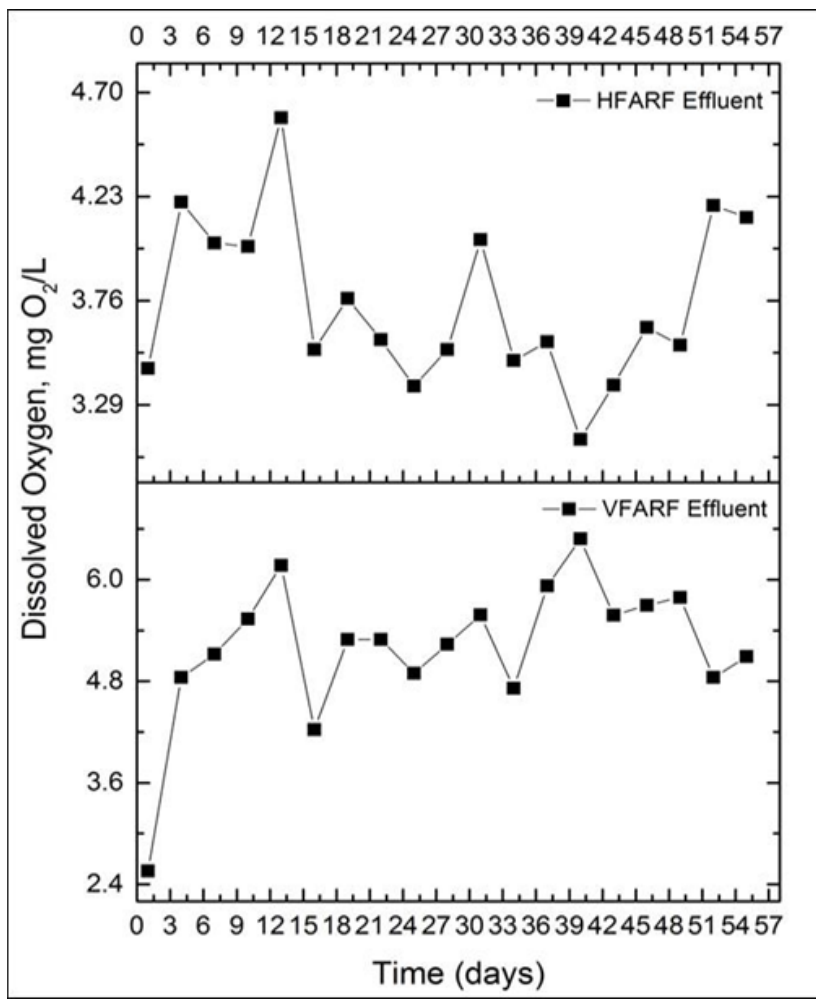

Figure 12. DO profiles of VFARF and HFARF effluent

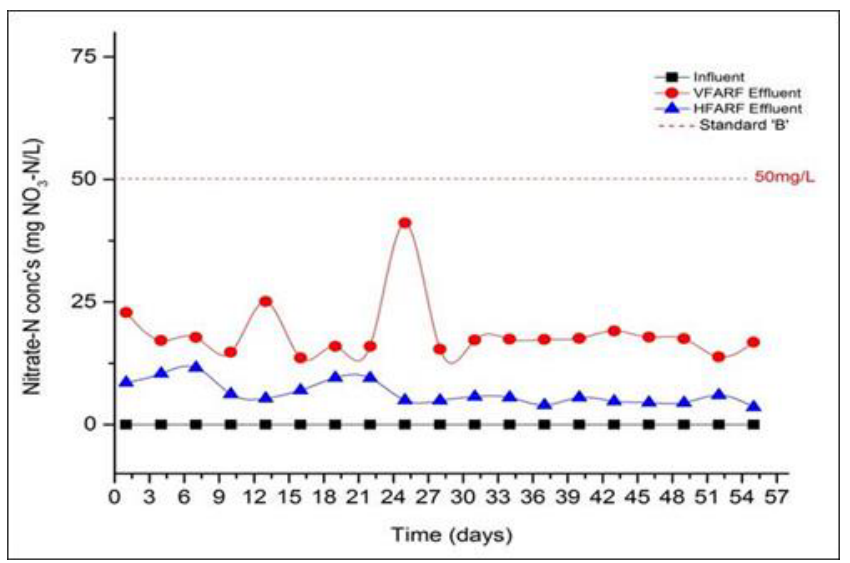

Figure 13. Nitrate-nitrogen concentrations in the WWTP influent and effluent of VFARF and HFARF 


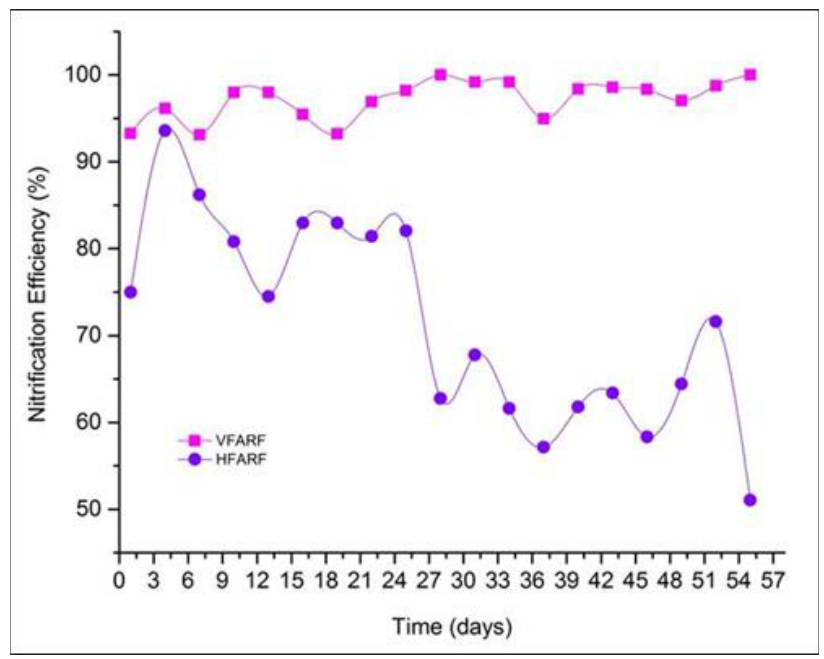

Figure 14. Nitrification efficiency of VFARF and HFARF systems

The average daily temperatures data were collected throughout this experimental period. The data was obtained from thermo button located at experimental station at WWTP Taman Bukit Perdana, Batu Pahat. The temperature profiles of VFARF and HFARF was given in Figure 15 which found to be within the range $28.0-$ $32.8^{\circ} \mathrm{C}$. Range of temperature during this experiment was undertaken fall within the optimum range of nitrification to take place as reported by Gerardi [10]. Therefore, it is expected that favourable environment also increased the nitrification rate during this study.

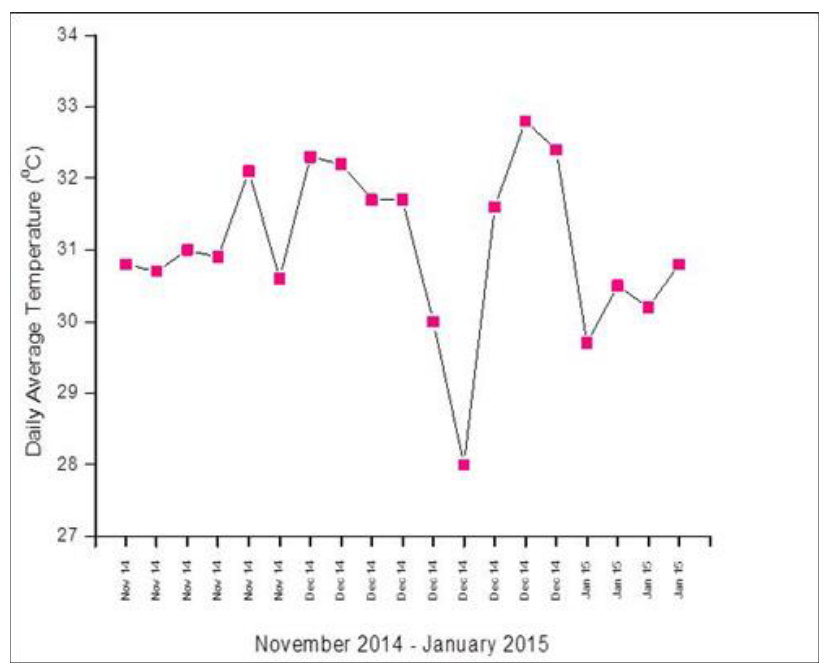

Figure 15. Temperature profile of WWTP influent and effluent of VFARF and HFARF

\section{$3.7 \mathrm{pH}$ and Alkalinity}

The $\mathrm{pH}$ value for influent concentration is in acidic $\mathrm{pH}$, i.e. 6.11-6.46 during the monitoring period. After treatment, the $\mathrm{pH}$ for VFARF and HFARF were in the neutral $\mathrm{pH}$ with an average of $7.14 \pm 0.27$ and $6.99 \pm$ 0.15 , respectively. This condition occurred most probably due to consumption of alkalinity since the nitrification of nitrogen within the treatment process. Figure 16 shows the $\mathrm{pH}$ profile in the influent and VFARF and HFARF during monitoring period.

The high alkalinity in the influent is in the range 180 to 900 of total alkalinity $\mathrm{mg} / \mathrm{L}$ as $\mathrm{CaCO}_{3}$ as can be seen in the Figure 17. Moreover, the total alkalinity was found to be further consumed rather than generated in VFARF and HFARF effluent. The alkalinity in the effluent from VFARF was lower than in the HFARF which is range from 77 to $175 \mathrm{mg} / \mathrm{L}$ as $\mathrm{CaCO}_{3}$ and 115 to $170 \mathrm{mg} / \mathrm{L}$ as $\mathrm{CaCO}_{3}$, respectively. This condition might be due to the nitrification rate which was significantly higher in the VFARF compared to the HFARF as both VFARF and HFARF systems were statistically significant different in terms of as the $p$-value was 0.000 .

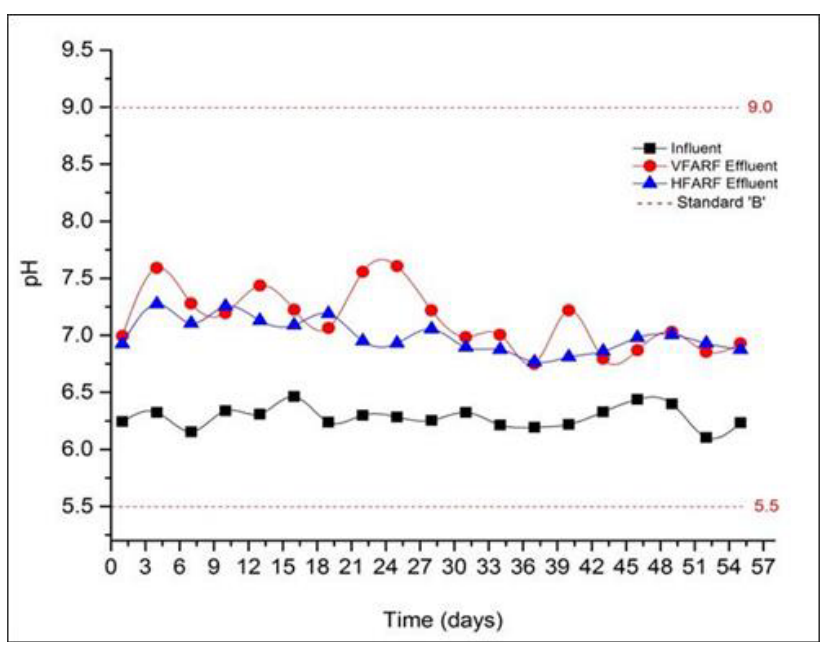

Figure 16. $\mathrm{pH}$ profile of WWTP influent and effluent of VFARF and HFARF

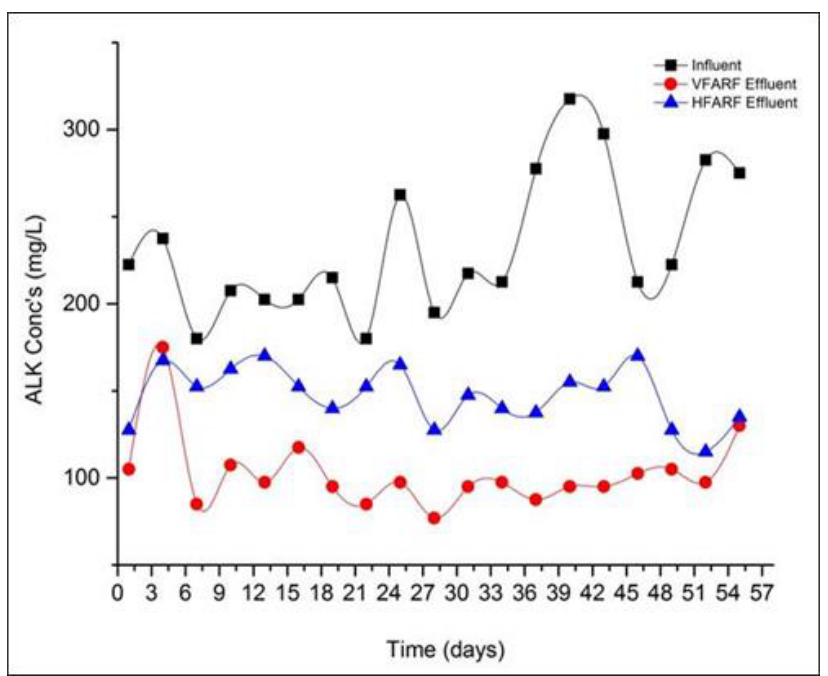

Figure 17. Alkalinity concentrations of WWTP influent and effluent of VFARF and HFARF

\subsection{Escherichia coli (E-coli)}

$E$-coli is naturally present in the intestinal tracts of warmblooded animals and is a member of the fecal coliform group of bacteria and also used as an indicator of fecal contamination of waterways [11]. The E-coli count from wastewater had an average of $50.949 \times 10^{3} \mathrm{cfu} / \mathrm{ml} \pm$ 
$29.9046 \times 10^{3} \mathrm{cfu} / \mathrm{ml}$ of influent concentration. E-coli were efficiently removed in the VFARF compared to the HFARF. The removal efficiency in the VFARF system is $97 \% \pm 2$, which produced an average of $1.40515 \times 10^{3}$ $\mathrm{cfu} / \mathrm{ml} \pm 1.5641110^{3} \mathrm{cfu} / \mathrm{ml}$ in the final effluent, meanwhile the removal efficiency in HFARF is $91 \% \pm 16$ with the final effluent concentration average is $2.9015 \mathrm{x}$ $10^{3} \mathrm{cfu} / \mathrm{ml} \pm 3.71592 \times 10^{3} \mathrm{cfu} / \mathrm{ml}$ as showed in Figures 18 and 19. Both VFARF and HFARF systems were efficiently removed $E$-coli from domestic wastewater and not statistically significant different in terms of effluent quality and removal efficiencies as the $p$-value was 0.315 and 0.165 respectively.

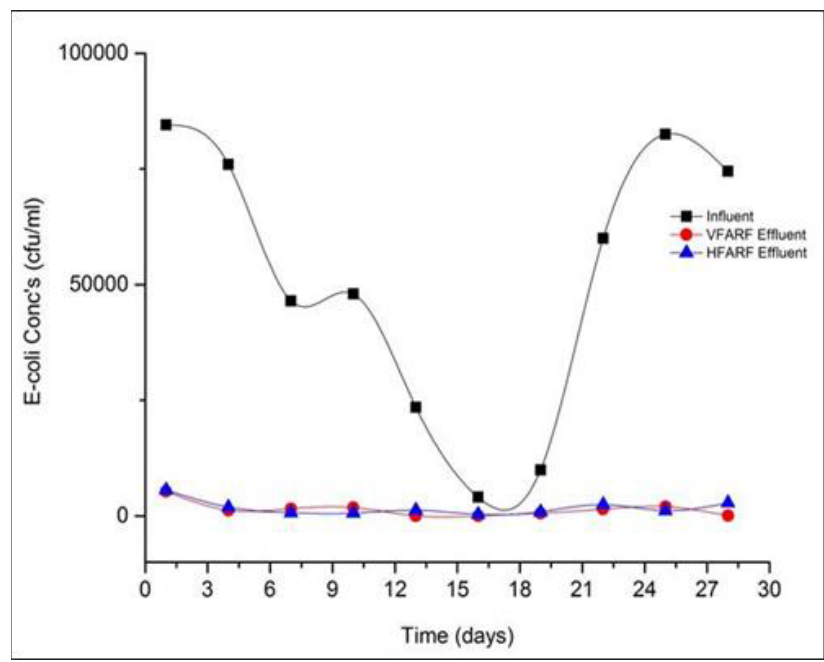

Figure 18. E-coli concentrations in the WWTP influent and effluent of VFARF and HFARF

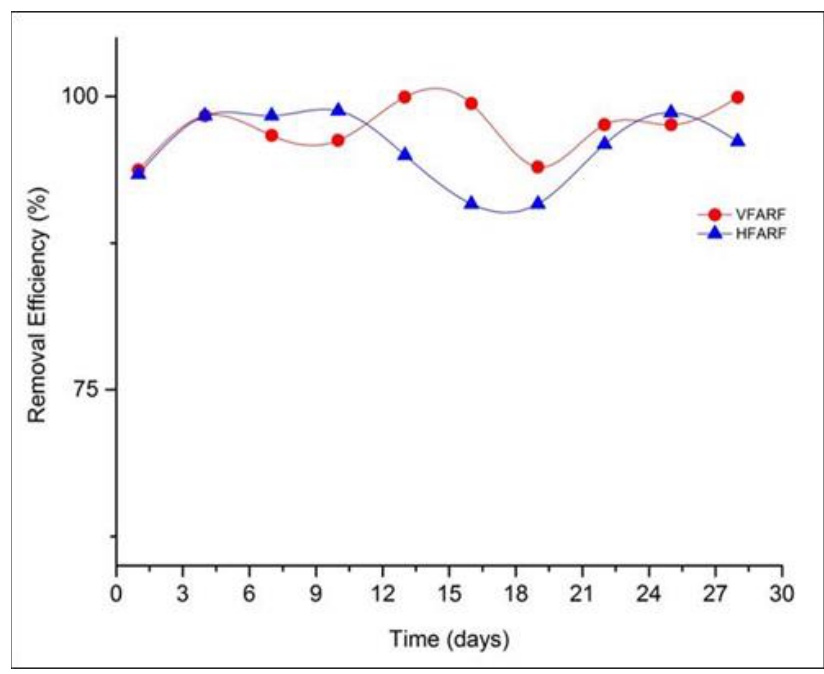

Figure 19. Removal efficiency of E-coli

\section{Conclusion}

Based on the experimental results reported herein, the objectives as presented in Chapter 1 (Section 1.3) have been achieved. A number of conclusions can be drawn from the present study are:

1. The VFARF system has emerged as one of the more competitive and economic treatment systems, particularly for nitrogen removal serving low-income and small communities' wastewater in comparison to the HFARF. Moreover, the VFARF system had a lower land area requirement than the HFARF.

2. The most effective degradation zone for $\mathrm{BOD}_{5}$, TSS, TKN, and ammonium-nitrogen is VFARF system.

3. Both systems are able to produce very good effluent quality as all the selected parameters were within the permissible limit of Standard B Malaysian Environmental Quality (sewage) Regulation 2009.

\section{Acknowledgement}

We are extremely grateful to all our funders: especially to Malaysian Ministry of Education under Exploratory Research Grant Scheme (Vot. E031), Universiti Tun Hussein Onn Malaysia and Indah Water Konsortium (IWK) for providing domestic wastewater sample. Last but not least; special thanks go to Perwaja Steel Sdn. Bhd., for kindly providing us steel slag for this project.

\section{References}

1. Chislock, M. F., Doster, E., Zitomer, R. A. and Wilson, A. E. (2013) Eutrophication: Causes, Consequences, and Controls in Aquatic Ecosystems. Nature Education Knowledge, 4(4):10.

2. Pramanik, B. K., Fatihah, S., Shahrom, Z., and Ahmed, E. (2012). Biological Aerated Filters (BAFs) for Carbon and Nitrogen Removal: A Review, 7(4), pp. 428-446.

3. Middlebrooks, E. J. (1988). Review of Rock Filters for the Upgrade of Lagoon Effluents. Journal Water Pollution Control Federation 60 (9) 1657-1662.

4. Johnson, M. and Mara D. D. (2005). Aerated rock filters for enhanced nitrogen and faecal coliform removal from facultative waste stabilization pond effluents. Water Science and Technology 51(12), 99-102.

5. Hamdan, R. (2010). Aerated Blast Furnace Slag Filters for Enhanced Nitrogen and Phosphorus Removal from Small WastewaterTreatment Plants. Ph.D. Thesis. The University of Leeds, School of Civil Engineering.

6. Standard Methods for the Examination of Water and Wastewater, 21st ed. (2005). American Public Health Association, Washington, DC.

7. Vymazal, J. (2005). Horizontal Sub-surface Flow and Hybrid Constructed Wetlands Systems for Wastewater Treatment. Ecological Engineering, 25(5), pp. 478-490. 
8. Albuquerque, A., Oliveira, J., Semitela, S., and Amaral, L. (2010). Evaluation of the Effectiveness of Horizontal Subsurface Flow Constructed Wetlands for Different Media. Journal of Environmental Sciences, 22(6), pp. $820-825$.

9. U. S. Environmental Protection Agency (2002). Rock Media Polishing Filter for Lagoons (Wastewater Technology Fact Sheet No. EPA 832-F-02-023). Washington, DC; US Environmental Protection Agency.

10. Gerardi, M. H. (2006). Wastewater Microbiology: Wastewater Bacteria, United States of America: John Wiley and Son, Inc., New York.

11. Ishii, S., and Sadowsky, M. J. (2008). Escherichia coli in the Environment: Implications for Water Quality and Human Health. Microbes and Environments, 23(2), pp. 101-108. 